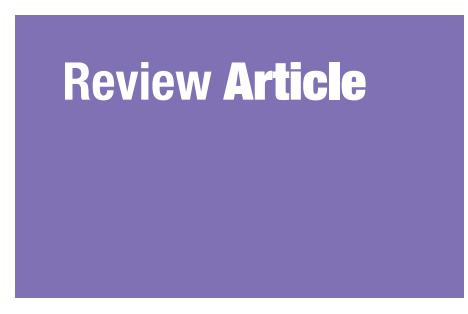

Submitted: 18 Nov 2017

Accepted: 21 Mar 2018

Online: 30 Oct 2018

\section{Roles and Prospects of Dengue Virus Non- structural Proteins as Antiviral Targets: An Easy Digest}

\author{
Hannah Norazharuddin, Ngit Shin LaI
}

Institute for Research in Molecular Medicine (INFORMM), Universiti Sains Malaysia, 1180 o USM, Pulau Pinang, Malaysia

To cite this article: Norazharuddin H, Lai NS. Roles and prospects of dengue virus non-structural proteins as antiviral targets: an easy digest. Malays J Med Sci. 2018;25(5):6-15. https://doi.org/10.21315/mjms2018.25·5.2

To link to this article: https://doi.org/10.21315/mjms2018.25.5.2

\begin{abstract}
Dengue is a neglected disease caused by the infection of dengue virus which is transmitted by Aedes mosquitoes and to some, it could be fatal. Regardless of the enormous work devoted to research for the treatment of dengue, to this day there is no cure, and treatment is solely limited to supportive care by treating the symptoms. The inhibition of the viral RNA non-structural enzymes has been the most popular approach amongst the strategies applied to the search and development of dengue antivirals. This review is a compact digest of what is already known of the roles and the prospects of the dengue virus non-structural proteins NS1, NS2BNS3, NS4A, NS4B and NS5 as the targets for antiviral studies including the recent progress that has been published regarding their roles.
\end{abstract}

Keywords: dengue virus, non-structural proteins, antiviral target

\section{Introduction}

The Dengue Virus (DENV) is an arthropodborne virus (arbovirus) of the Flaviviridae genus which also includes over 70 other important human pathogens such as Yellow Tick-Borne Encephalitis Virus (TBEV) (1). DENV is grouped into five serotypes, and these serotypes are antigenically distinct although closely related (DENV1, DENV2, DENV3, DENV4 and DENV5) with the fifth serotype recently discovered in late 2013 (2). Infection of this virus across different serotypes causes a range of illness extending from unapparent febrile illness, which often is diagnosed as Dengue Fever (DF) to an acute and potentially lethal hemorrhagic fever known as Dengue Hemorrhagic Fever (DHF) (3). The lifelong immunity provided by the recovery from the infection with one of the DENV serotypes is specifically against that particular serotype, but cross-immunity to the other serotypes is only partial and temporary. The transmitter mosquito Aedes is found in tropic and sub-tropic regions of the world, which includes parts of Indonesian archipelago into Northeastern Australia, South and Central America, Southeast Asia, SubSaharan Africa and some parts of the Caribbean. The occurrence of the disease has grown at an alarming rate around the world in recent decades with an estimation of 50-100 million infections worldwide every year (4).

Efforts to develop a vaccine for DENV have been in the works since in the early 1920 s. To date, there are a number of DENV vaccine candidates being developed and live attenuated vaccine candidates are the furthest in the development pipeline with a total of six in the clinical development stage $(5,6)$, such as TVoo3/ TVoo 5 by the US National Institutes of Health and Butantan, DENVax by Takeda and DEN$8 \mathrm{oE}$ by Merck to name a few. One finally made its way to the public after being approved in several countries according to the World Health Organization. The recently licensed vaccine is a tetravalent vaccine, appropriately named Dengvaxia $^{\circledR}$, developed by the pharmaceutical 
Review Article | Dengue virus non-structural protein as antiviral targets

giant Sanofi Pasteur (6). Despite the excitement over the vaccine, Malaysia has yet to make its decision on whether or not to roll out the vaccine for public use questioning its efficacy and economic impact (7). The question of the vaccine efficacy is highlighted as it shows variation by the recipient's age and serostatus, and also by the DENV serotype causing the infection with higher efficacy is witnessed in DENV 3 and 4 compared to DENV 1 and 2 (8).

As of now, there is no anti-viral drug that has been successfully developed albeit the increasing need. The current treatment is merely focused on treating the symptoms relying entirely on supportive care (9). Anti-viral approaches have explored structural and nonstructural proteins of DENV as targets. The usage of therapeutic antibodies is the most advanced intervention against virus entry although small molecules have been examined. The enzyme $\mathrm{NS}_{3}$ and $\mathrm{NS}_{5}$, along with $\mathrm{NS}_{4} \mathrm{~B}$ and $\mathrm{C}$ protein, are the main focus of the search for smallmolecule inhibitors. Studies have identified a number of compounds that can be successfully used as inhibitors (Table 1). Nevertheless, the only clinically investigated drug which is believed to directly target the viral protein $\mathrm{NS}_{5}$ is balapiravir, which is a nucleoside analogue originally developed for hepatitis C. However, a clinical trial showed that the drug did not meet efficacy endpoint (10).

\section{DENV Life Cycle and Protein Processing}

Flaviviruses are icosahedral in shape and encase a single-stranded, $\sim 11 \mathrm{~kb}$, positive-sense RNA genome (Figure 1) within its capsid protein in a host-derived lipid bilayer. Mature DENV virions consist of three structural proteins, the capsid protein $(\mathrm{C})$, membrane protein $(\mathrm{M})$, and the envelope protein $(\mathrm{E})$. The $\mathrm{C}$ protein $(11 \mathrm{kDa})$, in multiple copies, encapsulate the RNA genome forming the viral nucleocapsid. The nucleocapsid is surrounded by a host cell-derived lipid bilayer, in which 180 copies of $\mathrm{M}$ and $\mathrm{E}$ are anchored. The $\mathrm{M}$ protein is a small $(\sim 8 \mathrm{kDa})$ proteolytic fragment of its precursor form prM $(\sim 21 \mathrm{kDa})$. The $\mathrm{E}$ protein is sized at $53 \mathrm{kDa}$ and has three distinct structural domains (21).

The virus enters the host via a process of receptor mediated-endocytosis followed by fusion of the viral and vesicular membrane, allowing the release of the genomic RNA into the cytoplasm, serving as mRNA for replication and translation. The viral RNA carries an open reading frame (ORF) encoding a single polyprotein that is translated in a cap-dependent manner in the endoplasmic reticulum (ER) (22). The large viral polyprotein is co-translationally and post-translationally processed into three

Table 1. Prospective DENV anti-virals and their current status in drug development

\begin{tabular}{|c|c|c|c|}
\hline Compound & Mode of action & Current status & Reference \\
\hline Balapiravir & $\begin{array}{l}\text { NS5 polymerase nucleoside } \\
\text { analogue }\end{array}$ & $\begin{array}{l}\text { Showed no support for balapiravir as a } \\
\text { drug candidate }\end{array}$ & (10) \\
\hline 4-HPR & $\mathrm{NS}_{5}$ methyltransferase & $\begin{array}{l}\text { Showed efficacy in a mouse model, } \\
\text { tolerable human profile. }\end{array}$ & (11) \\
\hline Retrocyclin 1 & NS2BNS3 protease inhibitor & $\begin{array}{l}\text { Laboratory; significantly reduced viral } \\
\text { replication in DENV-2 infected Vero cells }\end{array}$ & (12) \\
\hline BP13944 & NS2BNS3 protease inhibitor & $\begin{array}{l}\text { Laboratory; reduced DENV replicon reporter } \\
\text { expression in cells, }(\mathrm{EC} 50) \text { of } 1.03 \pm 0.09 \mu \mathrm{M}\end{array}$ & (13) \\
\hline ST-148 & Capsid inhibitor & Preclinical development & (14) \\
\hline $\begin{array}{l}\text { ARDPooo6, } \\
\text { ARDPooo9 }\end{array}$ & NS2BNS3 protease inhibitor & $\begin{array}{l}\text { Laboratory; showed inhibition of DENV-2 } \\
\text { virus replication in cell culture. }\end{array}$ & (15) \\
\hline Ivermectin & NS3 Helicase & $\begin{array}{l}\text { Clinical trial estimated completion date on } \\
\text { February } 2016\end{array}$ & (16) \\
\hline ST-610 & NS3 Helicase & $\begin{array}{l}\text { Showed inhibition of all four DENV } \\
\text { serotypes in cell culture }\end{array}$ & (17) \\
\hline Suramin & NS3 Helicase & Potent NS3 helicase non-competitive inhibitor & (18) \\
\hline $\mathrm{AM}_{4} \mathrm{O} 4$ & $\mathrm{NS} 4 \mathrm{~B}$ & Showed inhibition of DENV replication & (19) \\
\hline Lycorine & $\mathrm{NS} 4 \mathrm{~B}$ & Potent inhibitor for flavivirus in cell culture & $(20)$ \\
\hline
\end{tabular}




\section{A) DENV genome}

5'UTR

(90-100nt)
ORF

$(+)$ single strand RNA $(\sim 11 \mathrm{~kb})$
3'UTR

(300-700nt)

\begin{tabular}{|c|c|}
\hline Structural & Non-structural \\
\hline
\end{tabular}

B) DENV polyprotein

\begin{tabular}{|l|l|l|l|l|l|l|l|l|l|}
\hline C & prM & E & NS1 & NS2A & NS2B & NS3 & NS4A & NS4B & NS5 \\
\hline
\end{tabular}

Figure 2. Structure of the DENV genome. A) The 5' end is capped with N7methylated guanosine cap while the 3' end forms a hairpin loop. The genome translates into B) a single polyprotein which will then be processed by the viral and host mechanism

structural proteins (C, prM, and E) located at the $\mathrm{N}$-terminal, and seven non-structural (NS) proteins (NS1, NS2A, NS2B, NS3, NS4A, NS4B, and NS5) are encoded at the C-terminal. The viral proteins prM, E, NS1, and NS4B are generated in the host's ER Lumen by utilising the host's ER signal peptidase which constructs the amino termini of prM, E, NS1, and NS4B by cleavage. The other NS proteins and the $\mathrm{C}$-terminus of the $\mathrm{C}$ protein are processed by the viral two-component protease $\mathrm{NS}_{2} \mathrm{~B}-\mathrm{NS}_{3}$ in the cytoplasm of the infected host. At a later stage of infection, a Golgi localised furin protease generates mature membrane protein $\mathrm{M}$ from its precursor prM (23).

\section{NS3 Helicase}

The protein $\mathrm{NS}_{3}$ of DENV is the second largest non-structural protein $(\sim 70 \mathrm{kDa})$ of the virus, and it has been found to exert numerous enzymatic activities during the virus replication. The $\mathrm{N}$-terminal region forms a serine protease needed for the polyproteinprocessing together with the protein $\mathrm{NS} 2 \mathrm{~B}$ as a co-factor. On the C-terminal of the protein, $\mathrm{NS}_{3}$ contains a nucleoside triphosphatase (NTPase), a 5' RNA-triphosphatase (RTP) and helicase in the remaining $70 \%$ of the protein (24). The helicase is essential for DENV replication process, and this has been shown by mutagenesis of the corresponding domain (25). The importance of NS3 protein for the survival of the virus makes it a suited target to be studied extensively as a drug target.
The helicase domain of $\mathrm{NS}_{3}$ (residues 180-618) comprises three sub-domains with structural and significant sequence identity resemblance to the helicases of another flavivirus (26). The ATPase/helicase and NTPase activities of DENV NS3 share the same active site and both C-terminal domain activities combined are required for melting secondary structures prior to initiation of RNA synthesis and for the unwinding of RNA duplexes, either to separate double-stranded RNA (dsRNA) intermediates formed during viral RNA synthesis or as a translocase that can remove proteins bound to viral RNA (27-29).

It was previously suggested that the protease domain exert significant regulatory role on flavivirus $\mathrm{NS}_{3}$ helicase activity due to an overlap region of 20 amino acids $(29,30)$. Despite the strong suggestions, the NS3 protease domain does not modulate the ATPase and helicase activities of DENV NS3. The helicase domain, encompassing amino acids 171 to 618 , has steady-state kinetic properties similar to that observed for the full-length $\mathrm{NS}_{3}$ with no critical differences between the two enzymes regarding RNA allosteric activation of ATP hydrolysis and RNA unwinding time courses (31). The virus loses its ability to replicate when its helicase activities are diminished, confirming the importance of the function of $\mathrm{NS}_{3}$ helicase domain in the continuation of the viral life cycle (25), and this prompts for development of the inhibitors or modulators of this enzyme as therapeutic agents (30).

A comprehensive list of helicase inhibitors listed six compounds as the inhibitor for 
flavivirus replication (32). Among them is Ivermectin. In silico docking of compounds into the single-strand RNA access site of WNV helicase identified Ivermectin which inhibited WNV, YFV, and DENV helicase dsRNA unwinding activity but not the $\mathrm{NS}_{3}$ ATPase activity. When tested in cell culture, ivermectin, that has been shown previously to inhibit DENV protease activity (15), inhibited YFV as well as DENV, JEV, WNV, and TBEV but with less potency (16). Ivermectin is a broadly used anti-helminthic drug and has been in clinical use for 25 years, yet it remains to be determined whether it would be efficacious with DENV. Another potential candidate for drug development is the small molecule ST610 which potently inhibited all four serotypes of DENV in cell culture (17). ST-610 inhibits DENV helicase RNA unwinding activity, but not ATPase activity. ST-610 showed marginal efficacy in the DENV AG-129 mouse model. The in vivo pharmacokinetic properties of this compound have much to be improved for further development.

\section{NS3 Protease (NS2BH-NS3pro)}

The DENV NS3 protease (NS3pro) is a trypsin-like serine protease that accommodates a typical serine protease catalytic triad comprising of the residues histidine 51 (His51), aspartic acid 75 (Asp75), and serine 135 (Ser135) located within 180 amino acids in the N-terminal onethird of the protein $(33,34,35)$. The catalytic activity of the protease enzyme requires the central $\sim 40$ residue hydrophilic domain from $\mathrm{NS} 2 \mathrm{~B}$ to function effectively (NS2BH-NS3pro) $(36,37)$. NS2BH-NS3pro only recognise sites with two cationic residues, unlike the conventional trypsin which recognises sites containing a single cationic residue (38). The protease cleaves the following sites: i) NS2A$\mathrm{NS}_{2} \mathrm{~B}, \mathrm{NS} 2 \mathrm{~B}-\mathrm{NS}_{3}, \mathrm{NS}_{3}-\mathrm{NS}_{4} \mathrm{~A}, \mathrm{NS}_{4} \mathrm{~B}-\mathrm{NS}_{5}$, ii) upstream of signal sequences at the C-prM and NS4A-NS4B junctions, iii) within NS2A, and also iv) within $\mathrm{NS}_{3}$ itself $(39,40)$.

With the need of both domains in order to function, NS2BH-NS3pro has been expressed by covalently linking the C-terminus of NS2BH cofactor to the N-terminus of NS3pro through a flexible 9-residue Gly4SerGly4 linker (41); and a more recent expression system of simultaneous uncoupled expression of NS2BH-NS3pro without the presence of a linker has been reported to dismiss the arguments of unknown effect of the artificial linker introduced between the protease and its cofactor that provide a more realistic model for screening inhibitors (42). The enzyme's substrate processing activity has shown to be affected by product release, suggesting a difference in conformation of the product-bound enzyme to the substrate-binding conformation and providing an important clue for alternative inhibitor design (42).

The engineering of the binding loop of aprotinin, a serine protease inhibitor which is potent against DENV NS3 protease $(41,43)$ shows that the prime side significantly modulates DENV protease binding affinity which could solve the hydrophilic and non-specific scaffolds resulting from the non-prime side. The tightest cyclic peptide achieved a Ki value of $2.9 \mu \mathrm{M}$ against $\mathrm{DENV}_{3}$ WT protease by optimising the cyclisation linker, length, and amino acid sequence of a series of cyclic peptides. This provides proof that both sides of the DENV protease active site have the potential to be explored in order to achieve specificity and lower hydrophilicity for the design of DENV inhibitors (44).

The DENV protease functions in a highly similar way to its HCV counterpart. Unlike $\mathrm{HCV}$, proteases from the four serotypes of DENV share similar substrate specificity and higher sequence similarity (45), imply that it is possible to develop a single inhibitory agent targeting all four dengue $\mathrm{NS}_{3}$ proteases. A benzimidazole derivative, named MB21, was found to be highly potent in inhibiting NS2BHNS3pro (IC50 $=5.95 \mu \mathrm{M}$ ) and was also found to be effective in inhibiting each one of the four serotypes of DENV in infected cells in culture, based on analysis of viral antigen synthesis and infectious virus production without showing any distinguishable cytotoxicity (46).

\section{NS5}

The NS5 protein is the largest and most conserved flaviviral protein of about 900 amino acids long and has the molecular mass of about $100 \mathrm{kDa}$ which harbours an RNAdependent RNA polymerase (RdRp) domain at its C-terminal end, which is immensely vital for the viral replication $(24,47)$. The large protein also contains a Capping enzyme site, which is made up of a methyltransferase (MTase) and guanylyltransferase (GTase) domain at its $\mathrm{N}$ terminus $(48-50)$. 
The NS5 capping enzyme (CE) has critical involvements in the mRNA capping process due to its methyltransferase (MTase) and guanylyltransferase (GTase) activities (33). The N-terminal of the $\mathrm{NS}_{5} \mathrm{CE}$ is responsible for transferring a guanosine monophosphate (GMP) from guanosine triphosphate (GTP) to the diphosphorylated RNA and for adding methyl groups to the guanine N-7 and ribose $2^{\prime}$ hydroxyl positions of the viral cap $(51,52)$.

Despite playing a central role in viral replication in the cytoplasm of infected host cells, the $\mathrm{NS}_{5}$ protein is located pre-dominantly in the nucleus of infected cells, which leads to the belief that it plays a role in the suppression of the host anti-viral response (53). The enzymatic activities of $\mathrm{NS}_{5}$ indicate the enzyme's standing role in the replication of the virus, playing a decisive role to preserve the virus longevity and survival, prompting $\mathrm{NS}_{5}$ as a promising anti-viral target $(11,54)$.

\section{NS1}

DENV non-structural protein 1 (NS1) is a glycoprotein with a molecular weight ranging from 46 to $55 \mathrm{kDa}$ due to its degree of glycosylation (55). The protein is expressed as a monomer, a membrane-bound dimer on the cell surface and secreted as a hexamer into the blood circulation of patients which forms an open barrel structure with three dimers forming a hydrophobic central cavity carrying 70 lipid molecules (56). The dimeric NS1 plays a pivotal role in the viral genome replication likely through interactions with NS4A and NS4B transmembrane proteins in the early stages of infection $(57,58)$.

Unlike the rest of the non-structural proteins, NS1 is noteworthy for being the target of dengue fever diagnostic kits. One rapid test is an Elisa based Platelia Dengue NS1 Ag assay developed by Bio-Rad in partnership with Pasteur Institute in France. The high levels of NS1 detected in patient's sera allows for the early diagnosis of dengue fever which drove the development of dengue diagnostic tests (59). The association of the NS1 antigen positivity with a higher risk of advancing to severe dengue can potentially be used as a test for the sign of severe dengue $(60,61)$.

The NS1 in hexameric form has long been hypothesised to play a role in dengue physiopathology due to its content of triglycerides, cholesterol, and phospholipids which is also present in high-density lipoproteins (HDL) suggesting that NS1 transports lipids in the plasma from tissues to the liver of dengue patients (62).

Recent findings have uncovered that $\mathrm{NS} 1$ activates macrophages via Toll-like receptor 4 (TLR4) and disrupts endothelial cells which cause vascular leakage, a distinct characteristic of dengue hemorrhagic fever (DHF) and dengue shock syndrome (DSS) $(63,64)$. This action is similar to the mechanism of septic shock in bacterial infections caused by bacterial cell wall products, indicating NS1 protein to be a viral toxin. This opens up a whole new avenue in repurposing clinically available drugs for dengue fever treatment.

\section{NS4A/B}

There is still more to be understood about the functions of the transmembrane proteins $\mathrm{NS} 4 \mathrm{~A}$ and NS4B. Instead of harbouring an enzymatic activity, these proteins act as scaffolds for the replication complex formation $(57,65)$. A transmembrane peptide named $2 \mathrm{~K}$ connects the two non-structural proteins together; it is then cleaved during the polyprotein maturation. NS4A has shown to induce the re-arrangement of the endoplasmic reticulum (ER) (66). NS4A also induces the localisation of the replication complex to be stabilised in the perinuclear area. This localisation is important due to the need for RNA viruses to use nuclear components for replication (67). In DENV infection, the stabilisation of the replication complex is mediated by the interaction of NS4A with the vimentin scaffold (68), which is a component of intermediary filaments for vesicular/organelle positioning and transport.

NS4B modulates the viral replication by its interaction with the helicase domain of $\mathrm{NS}_{3}$ to assist its dissociation from the viral RNA (69). Rather than having direct involvement with the viral genome replication process, NS4A participates in viral replication by inducing autophagy, hence protecting the cells from cell death during infection which is vital to viral replication (70).

\section{Conclusion}

To conclude, the DENV non-structural proteins play diverse yet vital roles in ensuring the survival of the virus. Abundant studies 
Review Article | Dengue virus non-structural protein as antiviral targets

done on the DENV non-structural proteins have shown that they are promising anti-viral targets. New roles and functions of these proteins have been uncovered, and this opens up many possibilities to manoeuvre research into finding the best anti-viral target. With the current urgency in finding the best treatment for dengue supported by the hints provided by the research done by various groups, we have to keep on moving towards discovering a cure for dengue fever.

\section{Acknowledgements}

This work was supported by Research University Individual grant (1001/CIPPM/ 8012305). The first author is the receiver of MyMaster scholarship.

\section{Conflicts of Interest}

None

\section{Funds}

None

\section{Authors' Contributions}

Conception and design: HN

Drafting of the article: HN

Critical revision of the article for important intellectual content: HN, LNS

Final approval of the article: LNS

\section{Correspondence}

Dr Lai Ngit Shin

Institute for Research in Molecular Medicine

(INFORMM),

Universiti Sains Malaysia,

11800 USM, Pulau Pinang, Malaysia.

Tel: +6046534862

Fax: +6046534803

E-mail: laingitshin@usm.my

\section{References}

1. Mackenzie JS, Gubler DJ, Petersen LR. Emerging flaviviruses: the spread and resurgence of Japanese encephalitis, West Nile and dengue viruses. Nat Med. 2004;10(12 Suppl):S98S109. https://doi.org/10.1038/nm1144
2. Mustafa MS, Rasotgi V, Jain S, Gupta V. Discovery of fifth serotype of dengue virus (DENV-5): a new public health dilemma in dengue control. Med $J$ Armed Forces India. 2015;71(1):67-70. https://doi.org/10.1016/j. mjafi.2014.09.011

3. Gubler DJ. Dengue and dengue hemorrhagic fever. Clin Microbiol Rev. 1998;11(3):480-496.

4. Bhatt S, Gething PW, Brady OJ, Messina JP, Farlow AW, Moyes CL, et al. The global distribution and burden of dengue. Nature. 2013;496(7446):504-507. https://doi.org/10. 1038/nature12060

5. McArthur MA, Sztein MB, Edelman R. Dengue vaccines: recent developments, ongoing challenges and current candidates. Expert Rev Vaccines. 2013;12(8):933-953. https://doi.org/1 $0.1586 / 14760584.2013 .815412$

6. Vannice KS, Durbin A, Hombach J. Status of vaccine research and development of vaccines for dengue. Vaccine. 2016;34(26):2934-2938. https://doi.org/10.1016/j.vaccine.2015.12.073

7. Lum M. Where are we with the dengue vaccine? [Internet]. 2016. [retrieved 2017 Jun 15]. Available from: http://www.star2.com/living/ viewpoints/2016/10/23/whither-the-denguevaccine/\#xKegr273KEevjUIv.99

8. Hadinegoro SR, Arredondo-García JL, Capeding MR, Deseda C, Chotpitayasunondh T, Dietze R, et al. Efficacy and long-term safety of a dengue vaccine in regions of endemic disease. $N$ Engl $J$ Med. 2015;373(13):1195-1206. https://doi.org/ 10.1056/NEJMoa1506223

9. Lee TH, Lee LK, Lye DC, Leo YS. Current management of severe dengue infection. Expert Rev Anti Infect Ther. 2017;15(1):67-78. https:// doi.org/10.1080/14787210.2017.1248405

10. Nguyen NM, Tran CNB, Phung LK, Duong KTH, Huynh HLA, Farrar J, et al. A randomized, double-blind placebo controlled trial of balapiravir, a polymerase inhibitor, in adult dengue patients. J Infect Dis. 2013;207(9):14421450. https://doi.org/10.1093/infdis/jis470

11. Lim SP, Noble CG, Shi P-Y. The dengue virus $\mathrm{NS}_{5}$ protein as a target for drug discovery. Antiviral Res. 2015;119:57-67. https://doi.org/10.1016/j. antiviral.2015.04.010 
12. Rothan HA, Han HC, Ramasamy TS, Othman S, Rahman NA, Yusof R. Inhibition of dengue NS2BNS3 protease and viral replication in vero cells by recombinant retrocyclin-1. BMC Infect Dis. 2012;12(1):1. https://doi.org/10.1186/1471-2334$12-314$

13. Yang CC, Hu HS, Wu RH, Wu SH, Lee SJ, Jiaang WT, et al. A novel dengue virus inhibitor, BP13944, discovered by high-throughput screening with dengue virus replicon cells selects for resistance in the viral $\mathrm{NS} 2 \mathrm{~B} / \mathrm{NS}_{3}$ protease. Antimicrob Agents Chemother. 2014;58(1):110119. https://doi.org/10.1128/AAC.01281-13

14. Byrd CM, Dai D, Grosenbach DW, Berhanu A, Jones KF, Cardwell KB, et al. A novel inhibitor of dengue virus replication that targets the capsid protein. Antimicrob Agents Chemother. 2013;57(1):15-25. https://doi.org/10.1128/AAC. 01429-12

15. Tomlinson SM, Watowich SJ. Anthracene-based inhibitors of dengue virus NS2B-NS3 protease. Antiviral Res. 2011;89(2):127-135. https://doi. org/10.1016/j.antiviral.2010.12.006

16. Mastrangelo E, Pezzullo M, De burghgraeve $\mathrm{T}$, Kaptein S, Pastorino B, Dallmeier K, et al. Ivermectin is a potent inhibitor of flavivirus replication specifically targeting $\mathrm{NS}_{3}$ helicase activity: new prospects for an old drug. $J$ Antimicrob Chemother. 2012;67(8):18841894. https://doi.org/10.1093/jac/dks147

17. Byrd CM, Grosenbach DW, Berhanu A, Dai D, Jones KF, Cardwell KB, et al. Novel benzoxazole inhibitor of dengue virus replication that targets the NS3 helicase. Antimicrob Agents Chemother. 2013;57(4):1902-1912. https://doi.org/10.1128/ AAC.02251-12

18. Basavannacharya C, Vasudevan SG. Suramin inhibits helicase activity of $\mathrm{NS}_{3}$ protein of dengue virus in a fluorescence-based high throughput assay format. Biochem Biophys Res Commun. 2014;453(3):539-544. https://doi.org/10.1016/j. bbrc.2014.09.113

19. Van Cleef KWR, Overheul GJ, Thomassen MC, Marjakangas JM, Van Rij RP. Escape mutations in $\mathrm{NS}_{4} \mathrm{~B}$ render dengue virus insensitive to the antiviral activity of the paracetamol metabolite AM404. Antimicrob Agents Chemother. 2016;60(4):2554-2557. https://doi.org/10.1128/ AAC.02462-15
20. Pheng S, Wang Q, Noble CG, Chen Y, Dong $\mathrm{H}$, Zou B, et al. Ten years of dengue drug discovery: progress and prospects. Antiviral Res. 2013;100(2):500-519. https://doi.org/10.1016/j. antiviral.2013.09.013

21. Rodenhuis-Zybert IA, Wilschut J, Smit JM. Dengue virus life cycle: viral and host factors modulating infectivity. Cell Mol Life Sci. 2010;67(16):2773-2786. https://doi.org/10.1007/ s00018-010-0357-z

22. Smit JM, Moesker B, Rodenhuis-Zybert I, Wilschut J. Flavivirus cell entry and membrane fusion. Viruses. 2011;3(2):160-171. https://doi. org/10.3390/v3020160

23. Fernandez-Garcia MD, Mazzon M, Jacobs M, Amara A. Pathogenesis of flavivirus infections: using and abusing the host cell. Cell Host Microbe. 2009;5(4):318-328. https://doi.org/ 10.1016/j.chom.2009.04.001

24. Gebhard LG, Filomatori CV, Gamarnik AV. Functional RNA elements in the dengue virus genome. Viruses. 2011;3(9):1739-1756. https:// doi.org/10.3390/v3091739

25. Matusan AE, Pryor MJ, Davidson AD, Wright PJ. Mutagenesis of the dengue virus type $2 \mathrm{NS}_{3}$ protein within and outside helicase motifs: effects on enzyme activity and virus replication. $J$ Virol. 2001;75(20):9633-9643. https://doi.org/10. 1128/JVI.75.20.9633-9643.2001

26. Luo D, Xu T, Hunke C, Gru G. Crystal structure of the $\mathrm{NS}_{3}$ protease-helicase from Dengue virus. $J$ Virol. 2008;82(1):173-183. https://doi.org/ 10.1128/JVI.01788-07

27. Lescar J, Luo D, Xu T, Sampath A, Lim SP, Canard B, et al. Towards the design of antiviral inhibitors against flaviviruses: the case for the multifunctional $\mathrm{NS}_{3}$ protein from dengue virus as a target. Antiviral Res. 2008;80(2):94-101. https://doi.org/10.1016/j.antiviral.2008.07.001

28. Xu T, Sampath A, Chao A, Wen D, Chene P, Vasudevan SG, et al. Structure of the dengue virus helicase/nucleoside triphosphatase catalytic domain at a resolution of $2.4 \AA$. $J$ Virol. 2005;79(16):10278-10288. https://doi.org/10. 1128/JVI.79.16.10278-10288.2005

29. Sampath A, Padmanabhan R. Molecular targets for flavivirus drug discovery. Antiviral Res. 2009;81(1):6-15. https://doi.org/10.1016/j. antiviral.2008.08.004 
30. Junaid M, Angsuthanasombat C, Wikberg JES, Ali N, Katzenmeier G. Modulation of enzymatic activity of dengue virus nonstructural protein $\mathrm{NS}_{3}$ nucleoside triphosphatase/helicase by poly(U). Biochemistry (Mosc). 2013;78(8):925-932. https://doi.org/10.1134/Sooo6297913080105

31. Gebhard LG, Kaufman SB, Gamarnik AV. Novel ATP-independent RNA annealing activity of the dengue virus $\mathrm{NS}_{3}$ helicase. PLoS One. 2012;7(4):27-29. https://doi.org/10.1371/ journal.pone.0036244

32. García LL, Padilla L, Castaño JC. Inhibitors compounds of the flavivirus replication process. Virol J. 2017;14(1):95. https://doi.org/10.1186/ s12985-017-0761-1

33. Liu L, Dong H, Chen H, Zhang J, Ling H, Li Z, et al. Flavivirus RNA cap methyltransferase: structure, function, and inhibition. Front Biol (Beijing). 2010;5(4):286-303. https://doi.org/ 10.1007/s11515-010-0660-y

34. Valle RPC, Falgout B. Mutagenesis of the NS3 protease of dengue virus type 2. J Virol. 1998;72(1):624-632.

35. Bazan JF, Fletterick RJ. Detection of a trypsinlike serine protease domain in flaviviruses and pestviruses. Virology. 1989;171(2):637-639.

36. Clum S, Ebner KE, Padmanabhan R. Cotranslational membrane insertion of the serine proteinase precursor $\mathrm{NS}_{2} \mathrm{~B}-\mathrm{NS}_{3}$ (Pro) of dengue virus type 2 is required for efficient in vitro processing and is mediated through the hydrophobic regions of NS2B. $J$ Biol Chem. 1997;272(49):30715-30723.

37. Yusof R, Clum S, Wetzel M, Murthy HM, Padmanabhan R. Purified NS2B/NS3 serine protease of dengue virus type 2 exhibits cofactor NS2B dependence for cleavage of substrates with dibasic amino acids in vitro. $J$ Biol Chem. 2000;275(14):9963-9969.

38. Ganesh VK, Muller N, Judge K, Luan CH, Padmanabhan R, Murthy KHM. Identification and characterization of nonsubstrate based inhibitors of the essential dengue and West Nile virus proteases. Bioorganic Med Chem. 2005;13(1):257-264. https://doi.org/10.1016/j. bmc.2004.09.036
39. Teo KF, Wright PJ. Internal proteolysis of the NS3 protein specified by dengue virus 2 . $J$ Gen Virol. 1997;78(2):337-341. https://doi. org/10.1099/0022-1317-78-2-337

40. Niyomrattanakit P, Winoyanuwattikun $P$, Chanprapaph S, Angsuthanasombat C, Panyim $\mathrm{S}$, Katzenmeier G. Identification of residues in the dengue virus type $2 \mathrm{NS} 2 \mathrm{~B}$ cofactor that are critical for $\mathrm{NS}_{3}$ protease activation. $J$ Virol. 2004;78(24):13708-13716. https://doi. org/10.1128/JVI.78.24.13708-13716.2004

41. Leung D, Schroder K, White H, Fang NX, Stoermer MJ, Abbenante G, et al. Activity of recombinant dengue 2 virus $\mathrm{NS}_{3}$ protease in the presence of a truncated $\mathrm{NS} 2 \mathrm{~B}$ co-factor, small peptide substrates, and inhibitors. $J$ Biol Chem. 2001;276(49):45762-45771. https://doi. org/10.1074/jbc.M107360200

42. Shannon AE, Chappell KJ, Stoermer MJ, Chow SY, Kok WM, Fairlie DP, et al. Simultaneous uncoupled expression and purification of the dengue virus $\mathrm{NS}_{3}$ protease and NS2B co-factor domain. Protein Expr Purif. 2016;119:124-129. https://doi.org/10.1016/j.pep.2015.11.022

43. Noble CG, Chen $\mathrm{Y}$, Dong $\mathrm{H}, \mathrm{Gu}$ F, Lim SP, Schul W, et al. Strategies for development of dengue virus inhibitors. Antiviral Res. 2010;85(3):450-462. https://doi.org/10.1016/j. antiviral.2009.12.011

44. Lin K-H, Ali A, Rusere L, Soumana DI, Yilmaz $\mathrm{NK}$, Schiffer CA. Dengue virus $\mathrm{NS} 2 \mathrm{~B} / \mathrm{NS}_{3}$ protease inhibitors exploiting the prime side. $J$ Virol. 2017;91(10):eooo45-17. https://doi.org/ 10.1128/JVI.00045-17

45. Li J, Lim SP, Beer D, Patel V, Wen D, Tumanut C, et al. Functional profiling of recombinant $\mathrm{NS}_{3}$ proteases from all four serotypes of dengue virus using tetrapeptide and octapeptide substrate libraries. J Biol Chem. 2005;280(31):2876628774. https://doi.org/10.1074/jbc.M500588200

46. Raut R, Beesetti H, Tyagi P, Khanna I, Jain SK, Jeankumar VU, et al. A small molecule inhibitor of dengue virus type 2 protease inhibits the replication of all four dengue virus serotypes in cell culture. Virol J. 2015;12(1):16. https://doi. org/10.1186/s12985-015-0248-x 
47. Davidson AD. Chapter 2. New insights into flavivirus nonstructural protein 5. Adv Virus Res. 2009;74:41-101. https://doi.org/10.1016/Soo653527(09)74002-3

48. Issur M, Geiss BJ, Bougie I, Picard-Jean F, Despins S, Mayette J, et al. The flavivirus NS5 protein is a true RNA guanylyltransferase that catalyzes a two-step reaction to form the RNA cap structure. RNA. 2009;15(12):2340-2350. https://doi.org/10.1261/rna.1609709

49. Henderson BR, Saeedi BJ, Campagnola G, Geiss BJ. Analysis of RNA binding by the dengue virus NS5 RNA capping enzyme. PLoS One. 2011;6(10):1-9. https://doi.org/10.1371/journal. pone.0025795

50. Coutard B, Decroly E, Li C, Sharff A, Lescar J, Bricogne $G$, et al. Assessment of dengue virus helicase and methyltransferase as targets for fragment-based drug discovery. Antiviral Res. 2014;106:61-70. https://doi.org/10.1016/j. antiviral.2014.03.013

51. Zhou Y, Ray D, Zhao Y, Ren S, Li Z, Guo Y, et al. Structure and function of flavivirus $\mathrm{NS}_{5}$ methyltransferase. Virol. J. 2007;81(8):38913903. https://doi.org/10.1128/JVI.02704-06

52. Barral K, Sallamand C, Petzold C, Coutard B, Collet A, Thillier Y, et al. Development of specific dengue virus 2'-O- and N7-methyltransferase assays for antiviral drug screening. Antiviral Res. 2013;99(3):292-300. https://doi.org/10.1016/j. antiviral.2013.06.001

53. Tay MYF, Fraser JE, Chan WKK, Moreland NJ, Rathore AP, Wang C, et al. Nuclear localization of dengue virus (DENV) 1-4 non-structural protein 5: protection against all 4 DENV serotypes by the inhibitor Ivermectin. Antiviral Res. 2013;99(3):301-306. https://doi.org/10.1016/j. antiviral.2013.06.002

54. Lai J-H, Lin Y-L, Hsieh S-L. Pharmacological intervention for dengue virus infection. Biochem Pharmacol. 2017;129:14-25. https://doi.org/10. 1016/j.bcp.2017.01.005

55. Muller DA, Young PR. The flavivirus NS1 protein: molecular and structural biology, immunology, role in pathogenesis and application as a diagnostic biomarker. Antiviral Res. 2013;98(2):192-208. https://doi.org/10.1016/j. antiviral.2013.03.008
56. Rastogi M, Sharma N, Singh SK. Flavivirus NS1: a multifaceted enigmatic viral protein. Virol $J$. 2016;13:131. https://doi.org/10.1186/s12985-0160590-7

57. Apte-Sengupta S, Sirohi D, Kuhn RJ. Coupling of replication and assembly in flaviviruses. Curr Opin Virol. 2014;9:134-142. https://doi. org/10.1016/j.coviro.2014.09.020

58. Avirutnan P, Fuchs A, Hauhart RE, Somnuke $\mathrm{P}$, Youn S, Diamond MS, et al. Antagonism of the complement component $\mathrm{C}_{4}$ by flavivirus nonstructural protein NS1. J Exp Med. 2010;207(4):793-806. https://doi.org/10.1084/ jem.20092545

59. Libraty DH, Young PR, Pickering D, Endy TP, Kalayanarooj S, Green S, et al. High circulating levels of the dengue virus nonstructural protein NS1 early in dengue illness correlate with the development of dengue hemorrhagic fever. $J$ Infect Dis. 2002;186(8):1165-1168. https:// doi.org/10.1086/343813

6o. Alcon S, et al. Enzyme-linked immunosorbent assay specific to dengue virus type 1 nonstructural protein NS1 reveals circulation of the antigen in the blood during acute phase of disease in patient experiencing primary or secondary infection. $A m$ J Trop Med Hyg. 2010;83(3):690-695.

61. Paranavitane SA, Gomes L, Kamaladasa A, Adikari TN, Wickramasinghe N, Jeewandara C, et al. Dengue NS1 antigen as a marker of severe clinical disease. BMC Infect Dis. 2014;14:570. https://doi.org/10.1186/s12879-014-0570-8

62. Gutsche I, Coulibaly F, Voss JE, Salmon J, Ermonval M, et al. Secreted dengue virus nonstructural protein NS1 is an atypical barrelshaped high-density lipoprotein. Proc Natl Acad Sci USA. 2011;108(19):8003-8008. https://doi. org/10.1073/pnas.1017338108

63. Modhiran N, Watterson D, Muller DA, Panetta AK, Sester DP, Liu L, et al. Dengue virus NS1 protein activates cells via Toll-like receptor 4 and disrupts endothelial cell monolayer integrity. Sci Transl Med. 2015;7(304):304ra142. https://doi. org/10.1126/scitranslmed.aaa3863 
Review Article | Dengue virus non-structural protein as antiviral targets

64. Chen H, Chuang Y, Lin Y, Liu H, Liu C-C, Perng $\mathrm{G}-\mathrm{C}$, et al. Dengue virus nonstructural protein 1 induces vascular leakage through macrophage migration inhibitory factor and autophagy. PLoS Negl Trop Dis. 2016;10(7):eooo4828. https://doi.org/10.1371/journal.pntd.ooo4828

65. Zou J, Xie X, Wang Q-Y, Dong H, Lee MY, Kang $\mathrm{C}$, et al. Characterization of dengue virus NS4A and NS4B protein interaction. $J$ Virol. 2015;89(7):3455-3470. https://doi.org/10.1128/ JVI.03453-14

66. Miller S, Kastner S, Krijnse-Locker J, Bühler S, Bartenschlager R. The non-structural protein $4 \mathrm{~A}$ of dengue virus is an integral membrane protein inducing membrane alterations in a $2 \mathrm{~K}$-regulated manner. J Biol Chem. 2007;282(12):8873-8882. https://doi.org/10.1074/jbc.M609919200

67. Hiscox JA. The interaction of animal cytoplasmic RNA viruses with the nucleus to facilitate replication. Virus Res. 2003;95(1-2):13-22.
68. Teo CSH, Chu JJH. Cellular vimentin regulates construction of dengue virus replication complexes through interaction with $\mathrm{NS} 4 \mathrm{~A}$ protein. J Virol. 2014;88(4):1897-1913. https:// doi.org/10.1128/JVI.01249-13

69. Umareddy I, Chao A, Sampath A, Gu F, Vasudevan SG. Dengue virus NS4B interacts with NS3 and dissociates it from single-stranded RNA. $J$ Gen Virol. 2006;87(9):2605-2614. https://doi. org/10.1099/vir.0.81844-0

70. McLean JE, Wudzinska A, Datan E, Quaglino D, Zakeri Z. Flavivirus NS4A-induced autophagy protects cells against death and enhances virus replication. J Biol Chem. 2011;286(25):2214722159. https://doi.org/10.1074/jbc.M110.192500 